\title{
Antibody response between pigs of Piau and a commercial breed naturally infected with Porcine circovirus 2
}

[Resposta sorológica entre suínos da raça Piau e linhagem comercial em rebanho naturalmente infectado pelo Porcine circovirus 2]

L.H.S. Bulos, N.F. Gonzaga, L.F.L. Souza, V.S. Assao, R.A.S. Leite, M.S. Rebouças, T.M. Scatamburlo, J.D. Guimarães S.E.F. Guimarães, P.S. Lopes, M.R.L. Almeida, A. Silva Júnior*

Universidade Federal de Viçosa - Viçosa, MG

\begin{abstract}
Brazilian pig population is made up of several naturalized breeds; among them the Piau breed is known for its rusticity and large fat stores. The naturalized breeds, in comparison with commercial ones, may have an increased resistance to diseases circulating in their territory. Thus, this study aimed to verify if there are differences between the serologic profile against Porcine circovirus 2 (PCV2) of Piau pigs and that of a commercial breed from a farm naturally infected by PCV2. The serum viral load was measured by qPCR, and levels of anti-PCV2 antibodies were measured by ELISA. The results showed that the serum viral load was similar across all animals. However, Piau piglets showed higher levels of antibodies compared to commercial piglets $(P=0.05)$, while sows of the commercial breed showed higher levels than the Piau breed $(P<0.01)$. There was not a statistical difference between pigs of different production stages in the seroprevalence of PCV2 or the blood viral load. This work demonstrates that, with regard to a natural PCV2 infection, the Piau breed has a different humoral immune response compared to the response developed by the commercial pigs. The results support the importance of conservation of native breeds.
\end{abstract}

Keywords:swine, serum viral load, serology, Piau

\section{RESUMO}

O rebanho de suínos brasileiro é constituído por diversas raças naturalizadas, entre elas a raça Piau, que é conhecida por sua rusticidade e pela grande deposição de toucinho. As raças naturalizadas, em comparação com as linhagens comerciais, podem ter uma maior resistência a doenças que circulam em seu território. Dessa forma, o presente estudo teve como objetivo verificar se existem diferenças no perfil sorológico contra o Porcine circovirus 2 (PVC2) entre suínos da raça Piau e de uma linhagem comercial de uma granja naturalmente infectada pelo PCV2. Foram realizadas mensurações da carga viral sérica por qPCR e dos níveis de anticorpos anti-PCV2 por meio da técnica de ELISA. Os resultados mostraram que a carga viral sérica se manteve homogênea em todos os animais e que os leitões da raça Piau apresentaram níveis de anticorpos superiores em comparação com os leitões da linhagem comercial $(P=0,05)$, enquanto as porcas de linhagem comercial apresentaram níveis superiores aos da raça Piau $(P<0,01)$. Este trabalho fornece indícios de que a raça Piau apresenta uma resposta imune humoral distinta diante de uma infecção natural pelo PCV2, quando comparada com a resposta desenvolvida pela linhagem comercial. Os resultados obtidos reforçam a importância da conservação das raças nativas.

Palavras-chave: suíno, viremia, sorologia, Piau

Recebido em 19 de maio de 2016

Aceito em 7 de junho de 2016

* Autor para correspondência (corresponding author)

E-mail: abelardo.junior@ufv.br 


\section{INTRODUCTION}

The Brazilian swine population is made up of several naturalized breeds, and among them the Piau breed is considered the most important (Sollero et al., 2006). The main characteristics of this breed are rusticity, low handling requirement and large fat stores, the latter of which is responsible for their classification as a "lard type" pig. Currently all the naturalized breeds are in danger of extinction, possibly due to the emergence of commercial pigs which are more productive (meat type) and better accepted in the market (Mariante et al., 2009).

The domestic-rural pigs had centuries to adapt to the environmental conditions of the country where they were created, and acquired unique characteristics such as rusticity, prolificity, and probably resistance to parasites and/or existing diseases found in different Brazilian regions (Egito et al., 2002). The importance of genetic diversity within the naturalized breeds is reflected in the wide range of types that exist and the variation inside each one. Studies of this diversity can assist in the development of future animal breeding programs (Egito et al., 2002).

Nowadays, Porcine circovirus 2 (PCV2) is widely distributed in commercial pigs from all over the world, and is responsible for causing a set of multifactorial syndromes collectively named PCV2 associated diseases (PCVDs) (Segalés et al., 2013). The PCVDs represent a health and economic challenge for the pig industry; among them the postweaning multisystemic wasting syndrome (PMWS) is the main syndrome because it is the leading cause of economic losses (Lópes-Soria et al., 2014).

The interaction between PCV2 and natural hosts (wild and domestic pigs) is a complex process that begins with viral adhesion and entry into the cell (Nauwynck et al., 2012). This interaction results in the development of an adaptive immune response which tends to end the acute infection, although some animals may develop the persistent infection (Segalés et al., 2012). This persistent infection is expected in animals that will develop subclinical disease but not in animals that will develop the systemic infection (Segalés et al., 2013).
Studies by Opriessnig et al. (2006, 2009) showed that purebred Landrace pigs developed more serious lymphoid lesions and clinical disease when compared to purebred Duroc, Large White, and Pietrain pigs. In a field observation study, Walgreen et al. (2009) demonstrated that Hampshire pigs developed less serious clinical signs from PCVDs than purebred animals like Landrace and Yorkshire pigs.

In the same context, Souza et al. (2011) demonstrated that Piau piglets may have a different immune response than piglets of commercial breeds; however, no other study has evaluated a similar hypothesis comparing naturalized with commercial breeds. Knowledge of the infection rates in these breeds is not clear, and the genetic influence on the pathogenesis of PCVDs is poorly discussed in the literature, although it is widely cited as a predisposing factor (Sliz et al., 2015).

Therefore, the goal of this study was to verify if there are differences between the immune response of pigs from Piau (naturalized) and a commercial breed on the same farm naturally infected with PCV2.

\section{MATERIAL AND METHODS}

The experimental procedures of this study are in accordance with the Ethics Committee on Animal Use of the Federal University of Viçosa (process number: 27/2013).

The animals used in this experiment were part of a non-vaccinated herd composed of the naturalized breed (Piau) and a commercial crossbreed (Landrace x Large White x Pietrain). All the animals came from the same swine farm with a farrow-to-finish system.

Calculation of the sample size was conducted using Epi Info software, version 3.5.1 (Statcalc calculator - sample size \& Power - population survey), using a prevalence of $95 \%$ for PCV2 infection (Barbosa et al., 2008), 5\% error and 95\% confidence interval. Cross-sectional data for the sample populations by stage of production are shown in (Table 1). 
Table 1. Population of animals and number of individuals considered for sampling in each production stage. $*$ The age of each production stage is given in weeks, except for sows which are given in number of parturitions

\begin{tabular}{ccccc} 
Production stage* & \multicolumn{2}{c}{ Herd } & \multicolumn{2}{c}{ Samples } \\
\cline { 2 - 5 } & Commercial & Piau & Commercial & Piau \\
\hline Sow (>2) & 67 & 23 & 9 & 9 \\
Farrowing (0-3) & 135 & 15 & 18 & 6 \\
Nursery (3-8) & 153 & 18 & 21 & 7 \\
Finishing (8-22) & 106 & 57 & 14 & 22 \\
\hline
\end{tabular}

Blood samples were collected by jugular venipuncture. The serum was separated and used in an in-house indirect anti-PCV2 IgG ELISA assay.

The capsid protein of PCV2 was expressed in E. coli and used as an antigen as described by Salgado et al. (2015). Ninety-six well microplates (Nunc Immuno ${ }^{\mathrm{TM}}$ MicroWell $^{\mathrm{TM}} 96$ Plates MaxiSorp ${ }^{\mathrm{TM}}$ Sigma-Aldrich, USA) were used and were coated with $5 \mu \mathrm{g} /$ well of antigen diluted in carbonate buffer $(0.05 \mathrm{M}, \mathrm{pH} 9.6)$ for twelve hours. The microplates were washed 4 times with phosphate buffered saline containing $0.05 \%$ of Tween 20 (PBS-T), blocked with PBS containing $3 \%$ of bovine serum albumin (BSA) and stirred for 90 minutes at room temperature. Then $100 \mu \mathrm{L}$ of the serum samples were diluted in PBS-T and added per well, at a final dilution of 1:400. Each sample was tested in duplicate. After washing again, the microplates were incubated with anti-swine $\mathrm{IgG}$ peroxidase conjugate produced in rabbits (Sigma-Aldrich, USA) at a dilution of 1:10,000 and stirred for 90 minutes at room temperature. Finally, $100 \mu \mathrm{L} /$ well of the substrate citrate-phosphate buffer $0.1 \mathrm{M}(\mathrm{pH} 5.0)$ containing $0.02 \% \mathrm{H}_{2} \mathrm{O}_{2}$ and $0.2 \mathrm{mg} / \mathrm{ml} \sigma$-phenylenediamine (OPD) was used and the microplate was incubated at room temperature. After 10 minutes, $50 \mu \mathrm{L} /$ well of $\mathrm{H}_{2} \mathrm{SO}_{4}$ solution $(1.5 \mathrm{M})$ was added, and the presence of antibodies was determined by reading the optical density (OD) at 492nm.

To determine if the animals were seropositive or seronegative for PCV2 the cut-off for each microplate was calculated according to the following formula: Cut-off $=\mathrm{OD}$ average negative control $+(2 *$ standard deviation of negative control).

Since all the wells were sensitized with the antigen, a modification was developed to increase accuracy of the readings. The antibody levels of each sample was calculated using the method of Fort et al. (2007): Sample to positive ratio $(\mathrm{S} / \mathrm{P})=(\mathrm{OD}$ sample $) /(\mathrm{OD}$ positive control OD negative control).

The percentage of positive and negative animals and the average level of anti-PCV2 antibodies for each production stage among the genotype groups were determined.

To determine the circulating viral load the serum samples were also tested by real-time polymerase chain reaction (qPCR) as described by Olvera et al. (2004). The method used was the hydrolyse probe $\left(\right.$ TaqMan $^{\circledR}$ ) system using the TaqMan Master Mix kit on the ABI Prism 7500 system (Applied Biosystems ${ }^{\mathrm{TM}}$, USA). Statistical analyses were performed using GraphPad PRISM $^{\circledR} 5$ (GraphPad Software, Inc., USA). The mean antibody level among the production stages within the same breed was determined using an analysis of variance with the Duncan test. The chi-square test was used to assess the antibody levels of the different production stages among the two genetic groups and to assess the differences in seroprevalence.

\section{RESULTS AND DISCUSSION}

Seropositivity of PCV2 in piglets $0-3$ weeks of age was $100 \%$, likely due to passive immunity from seropositive sows. Some authors observed that in farms with a farrow-to-finish cycle, the sows and the piglets in the farrowing had high antibody titers, indicating that there is a positive correlation between serum anti-PCV2 antibody titers in sows and the antibody levels in colostrum passively transferred to piglets (Gerber et al., 2012; 2014).

In both, 3-8 week stage and maternity stage (0-3 weeks), there was a lower prevalence of PCV2, 
likely due to decreased levels of antibodies from colostrum consumption. In the finishing stage (822 weeks of age), the number of seropositive animals increased again as a typical response of pigs to PCV2 in natural conditions. That means that there was a decrease in antibody titers from motherhood until the nursery stage, after which titers increased gradually until the finishing stage as observed by Fort et al. (2007) and Pinto et al. (2011) (Figure 1).

The average number of viral copies per milliliter was determined in each production stage of both breeds through qPCR technique (Table 2).
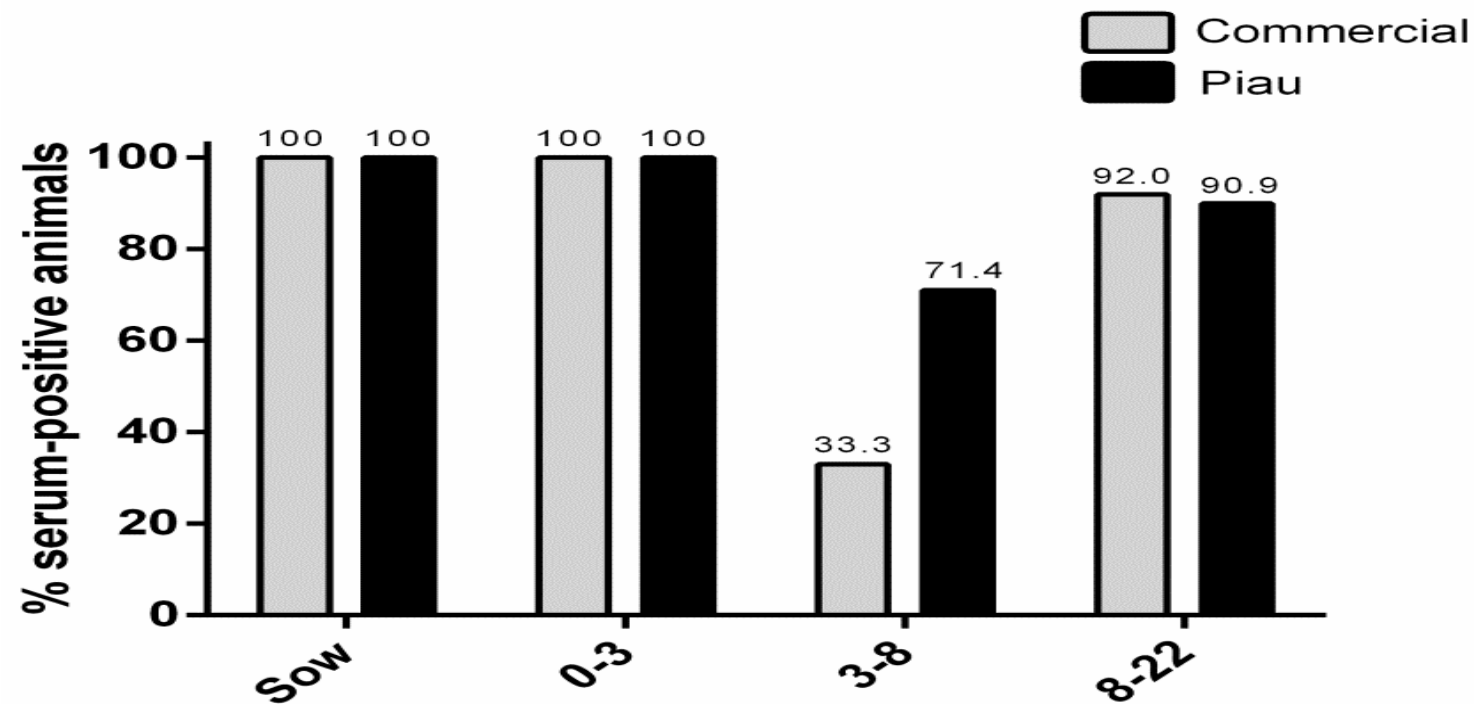

Figure 1. Percentage of animals seropositive for PCV2 in each production stage. Sow: more than two parturitions; maternity: 0-3 weeks of age; nursery: 3-8 weeks of age; finishing: 8-22 weeks of age.

Table 2. Mean and standard deviation of viral load $\left(\log _{10}\right.$ copies of PCV2/mL) in the different production stages of the Piau and the commercial breed

\begin{tabular}{clc}
\hline & \multicolumn{2}{c}{ Serum viral load/Sd** } \\
\cline { 2 - 3 } Production stage* & Commercial & Piau \\
\hline Sows $(>2)$ & $3.26( \pm 0.54)$ & $3.39( \pm 0.32)$ \\
Farrowing (0-3) & $3.77( \pm 1.09)$ & $3.18( \pm 0.28)$ \\
Nursery (3-8) & $3.46( \pm 0.35)$ & $3.18( \pm 0.59)$ \\
Finishing (8-22) & $3.49( \pm 0.38)$ & $3.18( \pm 0.59)$
\end{tabular}

* The age of each stage is given in weeks, except for the sows which is given as number of parturitions. **Sd=Standard deviation

The samples analyzed by qPCR were positive for the virus, and the virus was detected in all production stages as well as in both studied groups. However, there were no statistical differences observed when comparing the Piau with the commercial breed, in all indicating that the pressure of infection remained homogeneous in this farm.
Reiner et al. (2010) observed that wild animals showed lower viral loads in tissue samples $\left(10^{2.8}\right.$

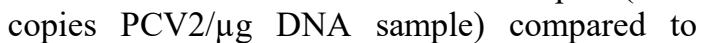
animals of commercial breeds $\left(10^{4.2}\right.$ copies PCV2/ $\mu$ g DNA sample), raising the hypothesis that there was a different response among those animals. In another study, Lunney and Chen (2010) suggested that genetic variations of the host regulate the responses of the innate and adaptive immune systems and also the 
mechanisms involved in specific disease resistance.

The serologic response of the sows was analyzed, and even though the two groups had the same serum load, the Piau breed showed lower levels of antibodies compared to the commercial breed $(\mathrm{P}<0.01)$ (Figure 2).

In nursery animals, 3-8 weeks of age, there were increased antibody levels in the Piau breed $(\mathrm{P}=$ $0.05)$.

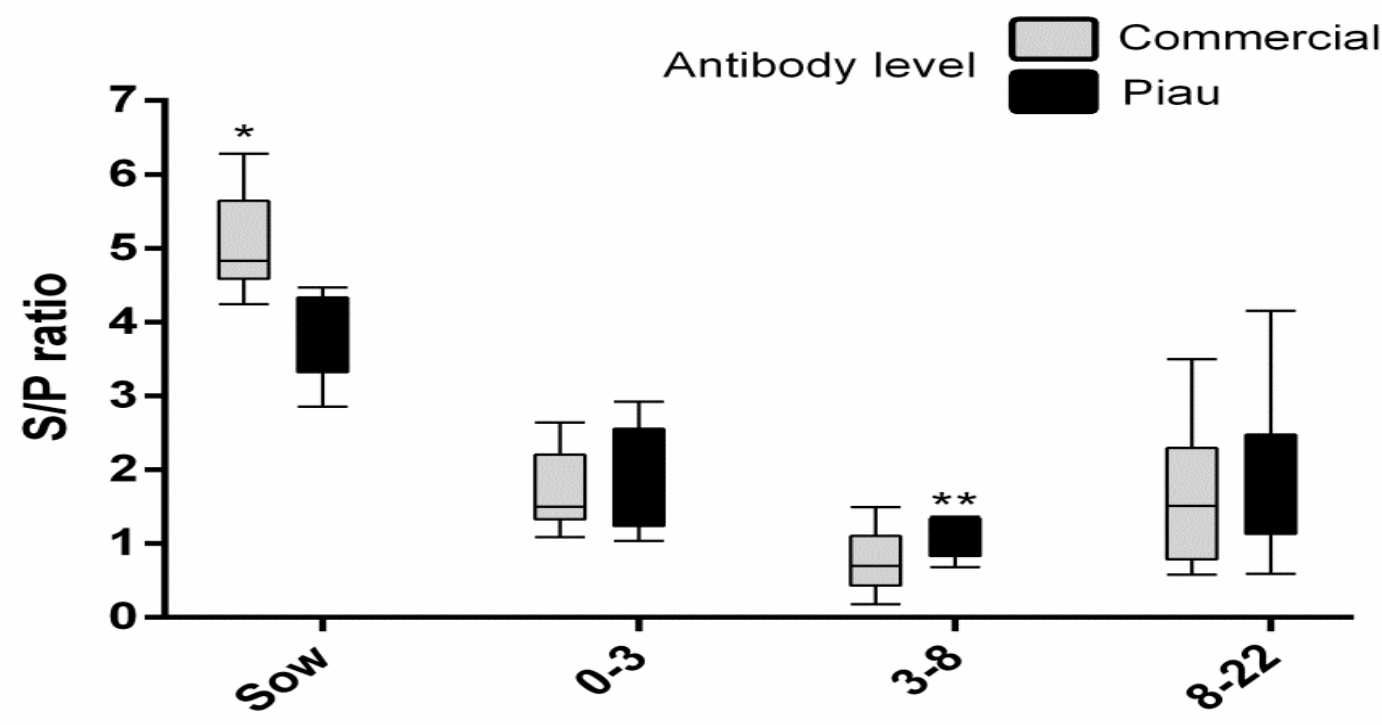

Figure 2. Serologic profile of the Piau and commercial breeds during the production phase. ${ }^{*} \mathrm{p}<0.01, * *$ $p=0.05$. Maternity: 0-3 weeks of age; nursery: 3-8 weeks of age; finishing: 8-22 weeks of age. The age for the sows is given in number of parturitions $(>2)$.

Several studies in humans and mice showed that increased body mass index or obesity can harm the efficiency of the immune system (Milner and Beck, 2012). Nieman et al.(1999) observed that $\mathrm{T}$ and $\mathrm{B}$ lymphocytes of obese humans have reduced proliferation when stimulated to undergo mitosis. O'Shea et al. (2013) observed that obese people have a weaker $\mathrm{T}$ lymphocyte response and increased production of IL-10 (interleukin suppressor). In another study, obese mice had decreased activation of cronatural killer cells, dendritic cells and TCD8+lymphocytes (Karlsson et al., 2010).

The Piau breed, like all swine breeds that have not gone through breeding program, had a higher potential to lipid synthesis (Serra et al., 1998). Serão et al. (2011) observed that the Piau breed has more intramuscular fat in the Longissimus dorsi muscle compared to commercial breeds, especially with regard to sows that are older animals and had excessive fat accumulation over time. Therefore, a possible explanation for the difference in the antibody response in the Piau breed is the higher percentage of fat stores compared to animals of commercial breed.

In farrowing, 0-3 weeks of age, there was not a statistical difference between the studied groups. We suggest that the Piau breed, although receiving a lower amount of maternal antibodies have a greater recovery of passive antibodies when compared to the commercial breed.

In nursery animals, 3-8 weeks of age, there were increased antibody levels in the Piau breed $(\mathrm{P}=$ $0.05)$. In the present work, Piau pigs at the end of the nursery phase (56 days of age) had an average weight of $14.64 \mathrm{~kg}$ and commercial pigs had an average weight of $20 \mathrm{~kg}$, therefore, there was unlikely to be an effect of excess body fat on the immune system of these animals, allowing them to react normally to an infection. This explains the higher antibody levels in nursery phase Piau pigs, which agrees with the theory 
that naturalized-rural breeds would be more resistant to pathogens (Amarante et al., 2009).

In the finishing stage, 8-22 weeks of age, there was no statistical difference between the studied groups. At this stage, there was an increase in the serologic response in both groups, as a typical response of positive pigs to PCV2, as observed by Fort et al. (2007) and Pinto et al. (2011).

The methodologies used in other studies to verify the difference in susceptibility to PCV2 infection would not apply to this study, because they were based on differences in the occurrence of clinical disease. The traditional way of evaluating the susceptibility difference to PCV2 subclinical infections is based on production parameters (Young et al., 2011), however the different productivity between the Piau and the commercial breed would make this methodology invalid (Veroneze et al., 2008). Therefore, this study showed that serologic analysis was the most appropriate methodology to evaluate the response of the two different genetic groups exposed to PCV2 infection.

This study demonstrated that the Piau breed has a humoral immune response different from that of the commercial breed regarding PCV2 infection, as the Piau sows had lower antibody levels, and the nursery piglets had higher antibody levels, compared to the commercial pigs. Importantly, infection prevalence was similar between the two groups, and the viral load found in both breeds did not differ statistically. These results reinforced the hypothesis that there were differences between the immune response of pigs from Piau and a commercial breed even when the pressure of infection was homogeneous in this farm.

\section{CONCLUSION}

The information obtained in this study reinforces the hypothesis that the Piau breed is an interesting model with which to study the immune response, because the Piau showed serologic differences compared to commercial pigs when undergoing similar pressure by PCV2 infection. Overall, more studies are needed to elucidate details about breed-dependent differences and the type and efficacy of immune response in the face of an infection.

\section{ACKNOWLEDGMENTS}

This study was supported by grants from the Fundação de Amparo à Pesquisa do Estado de Minas Gerais (FAPEMIG) and Conselho Nacional de Desenvolvimento Científico e Tecnológico (CNPq).

\section{REFERENCES}

AMARANTE, A.F.T.; SUSIN, I.; ROCHA, R.A. et al. Resistance of Santa Inês and crossbreed ewes to naturally acquired gastrointestinal nematode infections. Vet. Parasitol., v.165, p.273-280, 2009.

BARBOSA, C.N.; LOBATO, Z.I.P.; MARTINS, N.R.S. et al. Perfil sorológico para circovírus suíno tipo 2 em granjas comerciais de suínos no Brasil. Arq. Bras. Med. Vet. Zootec., v.60, p.815-820, 2008.

EGITO, A.A.; MARIANTE, A.S.; ALBUQUERQUE, M.S.M. Programa brasileiro de conservação de recursos genéticos animais. Arch. Zootec., v.51, p.3952, 2002.

FORT, M.; OLVERA, A.; SIBILA, M. et al. Detection of neutralizing antibodies in postweaning multisystemic wasting syndrome (PMWS)-affected and non-PMWS affected pigs. Vet. Microbiol., v.125, p.244-255, 2007.

GERBER, P.F.; GARROCHO, F.M.; LANA, A.M.Q. et al. Fetal infections and antibody profiles in pigs naturally infected with porcine circovirus type 2 (PCV2). Can. J. Vet. Res., v.76, p.38-44, 2012.

GERBER, P.F.; GARROCHO, F.M.; LOBATO, Z.I.P. The effects of sow viremia and maternal antibodies in porcine circovirus 2 on viral infection and weight of piglets. Arq. Bras. Med. Vet. Zootec., v.66, p.405-410, 2014.

KARLSSON, E.A; SHERIDAN, P.A.; BECK, M.A. Diet induced obesity impairs the $T$ cell memory response to influenza virus infection. J. Immunol., v.184, p.3127-3133, 2010.

LÓPEZ-SORIA, S.; SIBILA, M.; NOFRARÍAS, M. et al. Effect of porcine circovirus type 2 (PCV2) load in serum on average daily weight gain during the postweaning period. Vet. Microbiol., v.174, p.296-301, 2014.

LUNNEY, J.K.; CHEN, H. Genetic control of host resistance to porcine reproductive and respiratory syndrome virus (PRRSV) infection. Virus Res., v.154, p.161-169, 2010.

MARIANTE, A.S.; ALBUQUERQUE, M.S.M.; EGITO, A.A. et al. Present status of the conservation of livestock genetic resources in Brazil. Livest. Sci., v.120, p.204-212, 2009. 
MILNER, J.J.; BECK, M.A. Micronutrients, immunology and inflammation: the impact of obesity on the immune response to infection. Proc. Nutr. Soc., v.71, p.298-306, 2012.

NAUWYNCK, H.J.; SANCHEZ, R.; MEERTS, P. et al. Cell tropism and entry of porcine circovirus 2 . Virus. Res., v.164, p.43-45, 2012.

NIEMAN, D.C.; HENSON, D.A.; NEHLSENCANNARELLA, S.L. et al. Influence of obesity on immune function. J. Am. Diet. Assoc., v.99, p.294-299, 1999.

OLVERA, A.; SIBILA, M.; CASALMIGLIA, M. et al. Comparison of porcine circovirus type 2 load in serum quantified by a real time PCR in postweaning multisystemic wasting syndrome and porcine dermatitis and nephropathy syndrome naturally affected pigs. J. Virol. Methods, v.117, p.75-80, 2004.

OPRIESSNIG, T.; FENAUX, M.; THOMAS, M.J. et al. Evidence of breed-dependent differences in susceptibility to porcine circovirus type 2-associated disease and lesions. Vet. Pathol., v.43, p.281-293, 2006.

OPRIESSNIG, T.; PATTERSON, A.R.; MADSON, D.M. et al. Difference in severity of porcine circovirus type two-induced pathological lesions between landrace and pietrain pigs. J. Anim. Sci., v.87, p.15821590,2009

O'SHEA, D.; CORRIGAN, M.; DUNNE, M.R. et al. Changes in human dendritic cell number and function in severe obesity may contribute to increased susceptibility to viral infection. Int. J. Obes., v.37, p.1510-1513, 2013.

PINTO, F.F.; GERBER, P.F.; OLIVEIRA, T.M.L. et al. Serological profile, viremia and PCV2 shedding in naturally infected pigs of herds with or without postweaning multisystemic wasting syndrome. Pesqui. Vet. Bras., v.31, p.17-22, 2011.

REINER, G.; BRONNERT, B.; HOHLOCH, C. et al. Qualitative and quantitative distribution of PCV2 in wild boars and domestic pigs in Germany. Vet. Microbiol., v.145, p.1-8, 2010.

SALGADO, R.L.; VIDIGAL, P.M.; GONZAGA, N.F. et al. A porcine circovirus-2 mutant isolated in Brazil contains low-frequency substitutions in regions of immunoprotective epitopes in the capsid protein. Arch. Virol., v.160, p.2741-2748, 2015.
SEGALÉS, J. Porcine circovirus type 2 (PCV2) infections: clinical signs, pathology and laboratory diagnosis. Virus Res., v.164, p.10-19, 2012.

SEGALÉS, J.; KEKARAINEN, T.; CORTEY, M. The natural history of porcine circovirus type 2: From an inoffensive virus to a devastating swine disease? Vet. Microbiol., v.165, p.13-20, 2013.

SERÃO, N.V.; VERONEZE, R.; RIBEIRO, A.M.F. et al. Candidate gene expression and intramuscular fat content in pigs. J. Anim. Breed. Genet., v.128, p.2834, 2011.

SERRA, X.; GIL, F; PÉREZ-ENCISO, M. et al. A comparison of carcass, meat quality and histochemical characteristics of Iberian (Guadyerbas line) and landrace pigs. Livest. Prod. Sci., v.56, p.215-223, 1998.

SLIZ, I.; VLASAKOVA, M.; JACKOVA A. et al. Characterization of porcine parvovirus type 3 and Porcine circovirus type 2 in wild boars (Sus scrofa) in Slovakia. J. Wildl. Dis., v.51, p.703-711, 2015.

SOLLERO, B.P.; PAIVA, S.R.; FARIA, D.A. et al. Estrutura genética de cinco raças naturalizadas e comercias de suínos do Brasil, João Pessoa, PB. In: REUNIÃO ANUAL DA SOCIEDADE BRASILEIRA DE ZOOTECNIA, 43., João Pessoa. Anais... João Pessoa: SBZ, 2006. p.1-4. (Resumo).

SOUZA, K.R.S.; RIBEIRO, A.M.F.; GOES, P.R.N. et al. Toll-like receptor 6 differential expression in two pig genetic groups vaccinated against Mycoplasma hyopneumoniae. BMC Proc., v.5, suppl.4, p.1-8, 2011.

VERONEZE, R.; LOPES, M.S.; YAMAKI, M. et al. Estudo da curva de crescimento entre suínos de uma linhagem comercial e da raça Piau. In: SIMPÓSIO BRASILEIRO DE GENÉTICA ANIMAL, 7., 2008, São Carlos. Anais... São Carlos: SBMA, 2008. p.1-3. (Resumo).

WALLGREN, P.; BRUNBORG, I.M.; BLOMQVIST, G. et al. The index herd with PMWS in Sweden: presence of serum amyloid A, circovirus 2 viral load and antibody levels in healthy and PMWS-affected pigs. Acta Vet. Scand., v.51, p.13, 2009.

YOUNG, M.G.; CUNNINGHAM, G.L.; SANFORD, S.E. Circovirus vaccination in pigs with subclinical porcine circovirus type 2 infection complicated by ileitis. J. Swine Health Prod., v.19, p.175-180, 2011. 